九州大学学術情報リポジトリ

Kyushu University Institutional Repository

\title{
Predictive Models and Analys is of Peak and Flatten Curve Values of CoVID-19 Cases in India
}

Bhatnagar, Paras

Department of Mathematics, G. L. Bajaj Institute of Technology and Management

Kaura, Shivendra

Department of Electrical and Electronics Engineering, G. L. Bajaj Institute of Technology and Management

Rajan, Sanjeev

Department of Mathematics, Hindu College Moradabad

https://doi.org/10.5109/4150465

出版情報：Evergreen. 7 (4)，pp.458-467，2020-12. 九州大学グリーンテクノロジー研究教育センター バージョン：

権利関係 : 


\title{
Predictive Models and Analysis of Peak and Flatten Curve Values of CoVID-19 Cases in India
}

\author{
Paras Bhatnagar ${ }^{\left.{ }^{*}\right)}$, Shivendra Kaura ${ }^{2)}$, Sanjeev Rajan ${ }^{3)}$ \\ ${ }^{1}$ Department of Mathematics, \\ G. L. Bajaj Institute of Technology and Management, Greater Noida, UP, India \\ ${ }^{2}$ Department of Electrical and Electronics Engineering, \\ G. L. Bajaj Institute of Technology and Management, Greater Noida, UP, India \\ ${ }^{3}$ Department of Mathematics, Hindu College Moradabad, UP India \\ *Author to whom correspondence should be addressed: \\ E-mail: paras.bhatnagar@glbitm.ac.in (PB)
}

(Received 9 August 2020; Revised 20 October 2020; accepted 2 November 2020).

\begin{abstract}
Worldwide increasing cases of COVID-19 are putting high pressure on healthcare services. The coronavirus epidemic caused announcing emergency cases in India. The virus started with one infected case by $30^{\text {th }}$ January, 2020, in Kerala, where the first death due to corona in Karnataka and 73 announced cases were reported by $12^{\text {th }}$ March, 2020. 1024 announced cases were reported by $29^{\text {th }}$ March, 2020.This indicates that the number of confirmed cases is increasing rapidly, causing national crises for India. This study aims is to fill a gap between previous studies and the current development of COVID-19 spreading, by extracting a relationship between corona positives as independent and corresponding deaths as a dependent variable. This research statistically analyses the mortality in 10 days of every month. A mathematical model to predict the new deceased cases corresponding infected cases in a practical scenario is proposed. An approximate prediction of mortality corresponding to new predicted cases can be easily performed using the proposed model. As most of the other countries have reached their peaks, confirmed cases start decreasing. By analyzing these countries' data considering the lockdown, the peak ratio is identified using all countries' population and the decreasing rate of confirmed cases after the peak has been achieved. The same calculation has been done for death and recovered cases. This average peak ratio is used to identify India's COVID patients' peak value. The decreasing rate is also used to define the rate of confirmed cases and mortality after the peak has occurred. The model has also been verified in different countries to identify the significance of the model.
\end{abstract}

Keywords: COVID-19, Correlation, regression, a test of significance, Machine Learning.

\section{Introduction}

Saudi Arabia faced a novel virus called Middle East Respiratory Syndrome Coronavirus (MERS-CoV) in 2012, which belongs to the Coronavirus family. Infection with MERS-COV leaded to fatal complications. $\operatorname{In}^{1)}$ the authors developed several models to predict the cases' stability and chances of recovery in MERS-COV infected cases. The reports on COVID-19 indicated that it is a pneumonia like SARS, in which 26 to 33 per cent of patients required intensive care and the mortality rate 4 to $15 \%{ }^{2,3)}$. China ${ }^{4,5)}$, Lombardy, Italy ${ }^{6)}$ and New York, USA $^{7)}$ has described clinical presentation and early outcomes on the characteristics of COVID-19 patients.

Outbreaks of the COVID-19 epidemic have been causing worldwide health concerns since December 2019. The virus causes fever, cough, fatigue and mild to severe respiratory complications, which, if very severe, can lead the patient to death. On $6^{\text {th }}$ March, there were 98,192 cumulated cases of infection across the world and 3,045 deaths had been reported. On $11^{\text {th }}$ March, the virus outbreak was declared a pandemic by the World Health Organization $^{8)}$. So far, it has been reported that 13.8$19.1 \%$ of COVID-19-infected patients in Wuhan, China, became severely ill ${ }^{9,10)}$. Furthermore, recent reports have exposed an astonishing case fatality rate of $61.5 \%$ for critical cases and increasing sharply with age. The severity of cases puts great pressure on medical services, leading to a shortage of intensive care resources. Unfortunately, there is no currently available prognostic biomarker to distinguish patients that require immediate medical attention and to estimate their associated mortality rate. The capacity to identify cases that are at imminent risk of death has thus become an urgent yet challenging necessity.

The first case of Coronavirus CoVID-19 disease in India was announced on $30^{\text {th }}$ January $2020^{11)}$. India is considered as the largest country having confirmed cases 
in Asia. As of $11^{\text {th }}$ June 2020, the Ministry of Health and Family Welfare ${ }^{12)}$ have confirmed a total of 286,579 cases, 141,029 recoveries (including 1 migration) and 8,102 deaths in India $^{13)}$, while the global number of infected cases is 7255960 and number of confirmed deaths is 412583, referring to World Health Organization $(\mathrm{WHO})^{14)}$. In India, 1024 confirmed cases and 27 numbers of confirmed deaths were reported by $29^{\text {th }}$ March, 2020. By the time, the number of confirmed infected cases has been rapidly increased in India. The growth rate of confirmed cases was rapid until $29^{\text {th }}$ May, 2020, while India's fatality rate is relatively lower at $2.80 \%$, against the global $6.13 \%$ as of $3^{\text {rd }}$ June $2020^{15}$. People with low immunity, old age, and medical problems, specially related to lungs, are more prone to such cases. The rate of increasing cases in six cities

Mumbai, Delhi, Ahmedabad, Chennai, Pune and Kol kata is higher in India's reported cases in India.

Lakshadweep is reported as the only region without any confirmed cases on $24^{\text {th }}$ May, 2020.

This research statistically analyses the mortality rate in 10 days of every month. A new mathematical model to predict mortality rate corresponding to the new cases in the current scenario is proposed.

This research aims to study the mortality rate in an interval of 10 days of every month and develop a model to identify the COVID-19 spread in India by analyzing the data and ratios defined from the various fields available in different countries considering the complete lockdown or partial lockdown respectively. Based on real collected data and published reports this model can approximately predict the number of deaths due to Covid19. The study would give an overview of India's current situation besides, it may show the main parameters used to build a forecasting model.

COVID-19 cure and prediction are becoming a problem for almost all countries. The prediction of cases, their cure, mortality and recovery is becoming a hitch for us. Most of the countries are seeking for the peak, trying to flatten the curve. The top 15 countries are taking in our paper having maximum COVID-19 cases till 2nd June 2020 (Refer Figure: 1). It has also seen that besides lockdown, some countries like Italy, Spain, Germany, France, Korea ${ }^{16,17)}$ etc. are successful in achieving this. However some countries like India, Brazil, Chile, Peru, and Mexico are still looking for a peak point and reduction in cases to see the graph to be flattened. Also, it has been seen that top countries have the same trend as compared to each other, and lockdown is also having an approximately equal effect on the daily cases if we consider the population into account. When we compare the peak of these countries those achieved the flatten curve with their population, then some wonderful parameters came into consideration. By encountered these parameters in the prediction of COVID cases a graph has been prepared, a model \& graph has been built. After comparing the model R-Square, its relevance was established. The model has been built for daily confirmed cases, total cases, mortality \& recovery using the parameter developed, and graphs are plotted. Let us see how the model is predicting the cases.

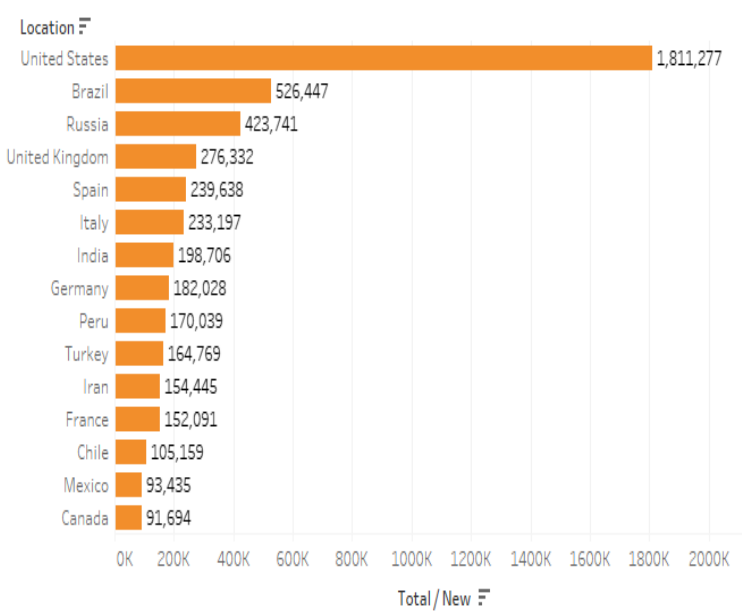

Figure. 1: Top 15 Countries with COVID Cases

\section{Dataset description}

We obtained our data set in table 1 from the data published by the Ministry of Health and Family Welfare on their website. We used the data on COVID-19 cases reported between $1^{\text {st }}$ March, 2020 and $8^{\text {th }}$ June, 2020. The data is published in the category of State/Union Territory wise per day new cases and deaths ${ }^{18)}$. A sample of the original dataset is given table no. 1. The dataset was published in different formats. Some of the records are available in text files some in the image and some tabulated form. Therefore, first we prepare data in a unified format appropriate for the regression model. To find our prediction model, we take the data (COVID-19 cases) in a sum of every 10 days of Months March, April, May and June respectively. The reason for taking 10 days is that if a person is infected in a particular day then he may recover or he may cause death within this duration. Suppose if all the persons infected in this duration recovered, then the recovery rate may be considered as $100 \%$. Similarly, if all the COVID-19 patients cause death, mortality can be considered $100 \%$ during this interval.

\section{Methodology}

We have taken the number of confirmed cases as an independent variable and number of deaths as a dependent variable. Both statistical analysis and t-test are used to analyze the collected data and ensure the impact of COVID-19 on mortality. First, we find the correlation coefficient between these two variables. In statistics, Correlation is a method used to appraise an approximate linear association between two continuous variables. Correlation is measured by Karl Pearson's coefficient $r$ that takes value in the range -1 to +1 which is a dimensionless quantity and represents the strength of 
linear association between two variables.

Then we use Student's t-test to confirm the average number of mortality rates with the previous number of cases. T-test also called the Student's t-test, is often used as a statistical method to assess whether the mean value of the data from an independent sample which follows a normal distribution is consistent with or depart significantly from the mean value of a null hypothesis, or whether the difference between the means of two independent samples which follow a normal distribution is statistically significant.

Table no. 1: Sample of the original dataset

\begin{tabular}{|c|l|c|c|c|}
\hline SN & \multicolumn{1}{|c|}{ Date } & $\begin{array}{c}\text { Cases } \\
(\mathbf{x})\end{array}$ & $\begin{array}{c}\text { Deaths( } \\
\mathbf{y})\end{array}$ & $\begin{array}{c}\text { Death rate (d) } \\
\mathbf{( \% )}\end{array}$ \\
\hline 1 & March-01-March-10 & 50 & 0 & 0 \\
\hline 2 & March-11-March-20 & 173 & 4 & 2.312138728 \\
\hline 3 & March-21-March-30 & 1028 & 28 & 2.723735409 \\
\hline 4 & March-31- April-9 & 4614 & 137 & 2.969224101 \\
\hline 5 & April-10- April-19 & 10251 & 350 & 3.414301044 \\
\hline 6 & April-20 - April-29 & 15671 & 489 & 3.120413503 \\
\hline 7 & April-30- May-09 & 27875 & 973 & 3.49058296 \\
\hline 8 & May-10- May-19 & 41477 & 1182 & 2.849772163 \\
\hline 9 & May-20- May-29 & 64660 & 1543 & 2.386328487 \\
\hline 10 & May-30- June-08 & 90812 & 2494 & 2.746333084 \\
\hline
\end{tabular}

\section{Results and Discussion}

The formula can calculate Karl Pearson's coefficient of Correlation

$$
r(x, y)=\frac{n \sum x y-\sum x \sum y}{\sqrt{n \sum x^{2}-\left(\sum x\right)^{2}} \sqrt{n \sum y^{2}-\left(\sum y\right)^{2}}}
$$

using table 1 we get the values from following table 2:

\begin{tabular}{|c|c|c|c|c|c|}
\hline $\begin{array}{l}\mathbf{S} \\
\mathbf{N}\end{array}$ & $\begin{array}{c}\text { Cases } \\
(\mathrm{x})\end{array}$ & $\begin{array}{c}\text { Deaths } \\
\text { (y) }\end{array}$ & $x y$ & $x^{2}$ & $y^{2}$ \\
\hline 1 & 50 & 0 & 0 & 2500 & 0 \\
\hline 2 & 173 & 4 & 692 & 29929 & 16 \\
\hline 3 & 1028 & 28 & 28784 & 1056784 & 784 \\
\hline 4 & 4614 & 137 & 632118 & 21288996 & 18769 \\
\hline 5 & 10251 & 350 & 3587850 & 105083001 & 122500 \\
\hline 6 & 15671 & 489 & 7663119 & 245580241 & 239121 \\
\hline 7 & 27875 & 973 & 27122375 & 777015625 & 946729 \\
\hline 8 & 41477 & 1182 & 49025814 & 1720341529 & 1397124 \\
\hline 9 & 64660 & 1543 & 99770380 & 4180915600 & 2380849 \\
\hline \multirow[t]{3}{*}{10} & 90812 & 2494 & 226485128 & 8246819344 & 6220036 \\
\hline & $\sum x$ & $\sum y$ & $\sum x y$ & $\sum x^{2}$ & $\sum y^{2}$ \\
\hline & 256611 & 7200 & 414316260 & $\begin{array}{c}1529813354 \\
9\end{array}$ & $\begin{array}{c}1132592 \\
8\end{array}$ \\
\hline
\end{tabular}

Using (1) and table 2, $r(x, y)=0.992310908$. This value of $r(x, y)$ shows the high degree positive correlation between $\mathrm{x}$ and $\mathrm{y}$. It indicates that the mortality rate will linearly increase with the increase of infected corona cases.

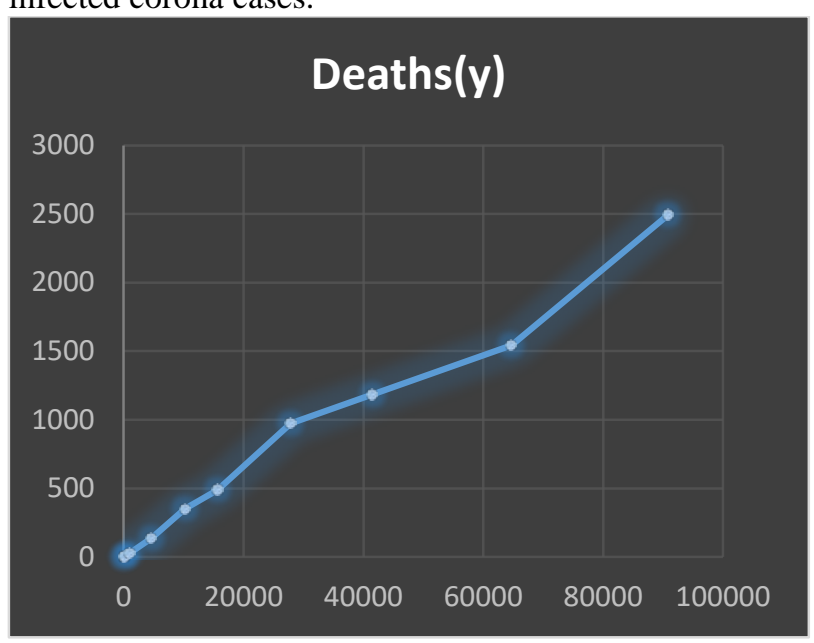

Figure 2: Curve of Distribution of death ${ }^{18)}$

It can be observed from the figure- 2 that the total number of cases increases rapidly with a small increase in death rate. For example, if infected cases increase from 4614 to 10251 cases, the total number of deaths increases from 137 to 350 .

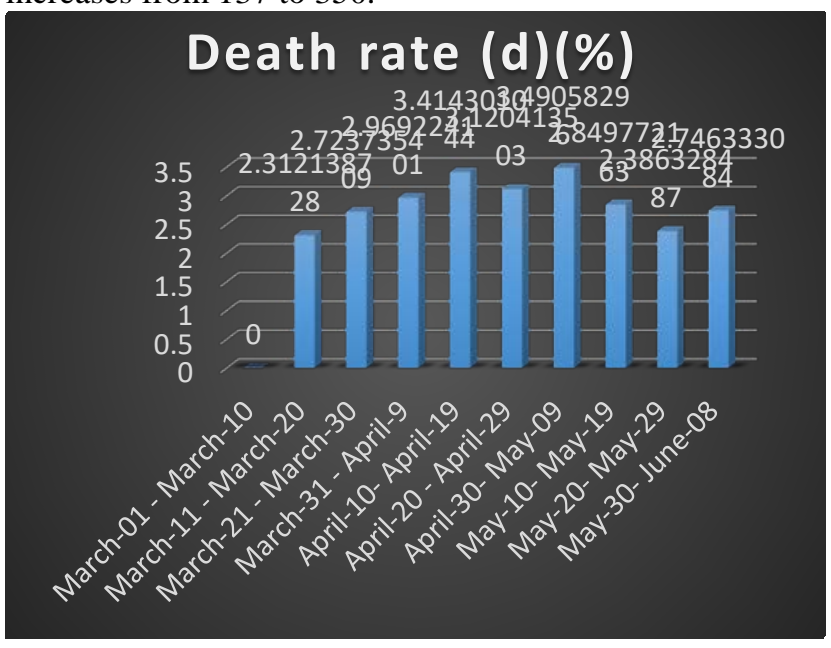

Figure 3: Mortality rate in India for different $\operatorname{cases}^{23)}$

Figure 3 shows the if we take the data in the group of $10-10$ days of the month; the average death rate is $2 . \%$ approximately.

\section{Hypothesis testing}

We test a null hypothesis that the maximum average fatality rate in India could be $3.49 \%$ (on behalf of table 1). A significant test can be done in order to determine whether the data is significant or not.

T-test: $T$-test is suitable for the small samples (such as $n<30$ ), in which the statistics follow a normal distribution but the standard deviation (SD) of the population is unknown. The test statistic is given by ${ }^{21)}$ 


$$
t=\frac{\bar{d}-\mu}{S / \sqrt{n}}
$$

Where $S=\sqrt{\frac{\sum(d-\bar{d})^{2}}{n-1}}, \bar{d}$ is the mean of $\mathrm{n}$ sample death rate and $\mu$ the average death rate in India, is taken as 3.49 .

Table no. 3: Calculation for test static $\mathrm{t}$

\begin{tabular}{|l|l|l|}
\hline SN & $d \%$ & $(d-\bar{d})^{2}$ \\
\hline 1 & 0 & 6.68626338 \\
\hline 2 & 2.312138728 & 0.07488009 \\
\hline 3 & 2.723735409 & 0.01903142 \\
\hline 4 & 2.969224101 & 0.14702861 \\
\hline 5 & 3.414301044 & 0.68644546 \\
\hline 6 & 3.120413503 & 0.28583191 \\
\hline 7 & 3.49058296 & 0.81866659 \\
\hline 8 & 2.849772163 & 0.06969133 \\
\hline 9 & 2.386328487 & 0.0397813 \\
\hline 10 & 2.746333084 & 0.02577697 \\
\hline & & $\sum(d-\bar{d})^{2}=$ \\
& $\sum d=$ & 8.85339708 \\
\hline
\end{tabular}

Using (2) and table 3, $|t|=2.833542928$.

At $1 \%$ level of significance and 9 degrees of freedom, this result confirms our null hypothesis that India's maximum average death rate could be $3.49 \%$.

\section{Predictive Models for Covid-19 patients}

We have taken several confirmed cases as an independent variable and the number of deaths as dependent variable.

\section{Least Square approximation}

If the function $y=f(x)$ is to be approximated to $\mathrm{P}(\mathrm{x})$ then by the Least square method ${ }^{22)}$, the error function $u=\sum W(x)[f(x)-P(x)]^{2}$ for discrete points $x_{1}, x_{2} \ldots . x_{n}$.

Where $W(x)>0$ is the weight function, $P(x)=C_{1} \phi_{1}(x)+C_{2} \phi_{2}(x)+\ldots . . C_{n} \phi_{n}(x), C_{1}, C_{2}$,
$C_{n}$ are constants and $\phi_{i}(x)$ is called the coordinate function.

$|f(x)-P(x)|=E(f, c)=E$,

is called error of approximation.

For u to be minimum

$\frac{\partial u}{\partial C_{i}}=0, \quad i=0,1,2, \ldots . . n$.

These equations are called normal equations.

Consider a linear curve of regression

$$
P(x)=C_{1}+C_{2}(x)+E(f, C),
$$

where $C_{2}=\frac{n \sum x y-\sum x \sum y}{n \sum x^{2}-\left(\sum x\right)^{2}}$,

$C_{1}=\bar{y}-C_{2} \bar{x}$ and $W(x)=1$.

Using table 1 we get

$P(x)=43.93846163+.026345774 x+E$

Accuracy of the model can be calculated by

Accuracy $=\operatorname{Avg}\left(\frac{\text { Absolute }(\text { Actual }- \text { Forecast })}{\text { Absolute }(\text { Actual })}\right) \times 100$

To find the values of $C_{1}$ and $C_{2}$, we have considered the cases from $1^{\text {st }}$ March, 2020 to $8^{\text {th }}$ June, 2020, given in table 1 , the rest of the data is used to test this model.

Performance and evaluation of regression model

\begin{tabular}{|c|c|c|c|c|c|c|}
\hline Date & $\begin{array}{c}\text { Ac } \\
\text { tua } \\
1 \\
\text { cas } \\
\text { es }\end{array}$ & $\begin{array}{c}\text { Act } \\
\text { ual } \\
\text { deat } \\
\text { hs }\end{array}$ & $\begin{array}{l}\text { Model } \\
\text { predicte } \\
\text { d } \\
\text { deaths }\end{array}$ & $\begin{array}{l}\text { Error } \\
|E|\end{array}$ & $\begin{array}{l}\text { Actual } \\
\text { rate (\%) }\end{array}$ & $\begin{array}{c}\text { Model } \\
\text { predicte } \\
\text { d } \\
\text { death } \\
\text { rates } \\
\text { (\%) }\end{array}$ \\
\hline $\begin{array}{l}\text { Jun- } \\
02\end{array}$ & $\begin{array}{l}81 \\
71\end{array}$ & 204 & $\begin{array}{l}259.209 \\
781\end{array}$ & $\begin{array}{l}55.20 \\
978\end{array}$ & $\begin{array}{l}2.49663 \\
4439\end{array}$ & $\begin{array}{l}3.17231 \\
4049\end{array}$ \\
\hline $\begin{array}{l}\text { Jun- } \\
03\end{array}$ & $\begin{array}{l}89 \\
09\end{array}$ & 217 & $\begin{array}{l}278.652 \\
9622\end{array}$ & $\begin{array}{l}61.65 \\
296\end{array}$ & $\begin{array}{l}2.43573 \\
914\end{array}$ & $\begin{array}{l}3.12776 \\
9247\end{array}$ \\
\hline $\begin{array}{l}\text { Jun- } \\
04\end{array}$ & $\begin{array}{l}93 \\
04\end{array}$ & 260 & $\begin{array}{l}289.059 \\
5429\end{array}$ & $\begin{array}{l}29.05 \\
954\end{array}$ & $\begin{array}{l}2.79449 \\
6991\end{array}$ & $\begin{array}{l}3.10683 \\
0857\end{array}$ \\
\hline $\begin{array}{l}\text { Jun- } \\
05\end{array}$ & $\begin{array}{l}98 \\
51\end{array}$ & 273 & $\begin{array}{l}303.470 \\
6813\end{array}$ & $\begin{array}{l}30.47 \\
068\end{array}$ & $\begin{array}{l}2.77129 \\
2255\end{array}$ & $\begin{array}{l}3.08060 \\
787\end{array}$ \\
\hline Jun- & 98 & 294 & 304.419 & 10.41 & 2.97360 & 3.07898 \\
\hline
\end{tabular}

Table no. 4: Performance of the model 


\begin{tabular}{|c|c|c|c|c|c|c|}
\hline 06 & 87 & & 1292 & 913 & 1699 & 3809 \\
\hline $\begin{array}{l}\text { Jun- } \\
07\end{array}$ & $\begin{array}{l}99 \\
71\end{array}$ & 287 & $\begin{array}{l}306.632 \\
1742\end{array}$ & $\begin{array}{l}19.63 \\
217\end{array}$ & $\begin{array}{l}2.87834 \\
7207\end{array}$ & $\begin{array}{l}3.07523 \\
9938\end{array}$ \\
\hline $\begin{array}{l}\text { Jun- } \\
08\end{array}$ & $\begin{array}{l}99 \\
83\end{array}$ & 271 & $\begin{array}{l}306.948 \\
3235\end{array}$ & $\begin{array}{l}35.94 \\
832\end{array}$ & $\begin{array}{l}2.71461 \\
4845\end{array}$ & $\begin{array}{l}3.07471 \\
0242\end{array}$ \\
\hline $\begin{array}{l}\text { Jun- } \\
09\end{array}$ & $\begin{array}{l}99 \\
87\end{array}$ & 271 & $\begin{array}{l}307.053 \\
7066\end{array}$ & $\begin{array}{l}36.05 \\
371\end{array}$ & $\begin{array}{l}2.71352 \\
7586\end{array}$ & $\begin{array}{l}3.07453 \\
396\end{array}$ \\
\hline $\begin{array}{l}\text { Jun- } \\
10\end{array}$ & $\begin{array}{l}99 \\
85\end{array}$ & 274 & $\begin{array}{l}307.001 \\
015\end{array}$ & $\begin{array}{l}33.00 \\
102\end{array}$ & $\begin{array}{l}2.74411 \\
6174\end{array}$ & $\begin{array}{l}3.07462 \\
2083\end{array}$ \\
\hline $\begin{array}{l}\text { Tot } \\
\text { al }\end{array}$ & $\begin{array}{l}86 \\
04 \\
8\end{array}$ & $\begin{array}{l}235 \\
1\end{array}$ & $\begin{array}{l}2662.44 \\
7316\end{array}$ & $\begin{array}{l}311.4 \\
473\end{array}$ & $\begin{array}{l}2.74411 \\
6174\end{array}$ & $\begin{array}{l}3.07462 \\
2083\end{array}$ \\
\hline
\end{tabular}

In table no. 4, the performance of the model (3) is evaluated and compared with available data. In general, the accuracy of the model is between 71.59 to 96.45 . It is believed that the accuracy of the model can be enhanced with the use of more collected data of further Covid-19 cases.

\section{A predictive model of COVID Confirmed Cases:}

A data of Top 15 countries $^{23)}$ having the highest COVID cases is taken for the calculation. The graphs of countries are plotted against days to see the pattern of daily COVID confirmed cases. Among them we found 10 countries have reached the peak and also reverse cycle has been achieved in decreasing the total daily cases of COVID. So from these 15 countries, 10 countries are taken in the calculation. The confirmed cases graphs of these countries are plotted (using machine learning algorithm) ${ }^{24)}$ in figure $^{23)} 4,5,6$.

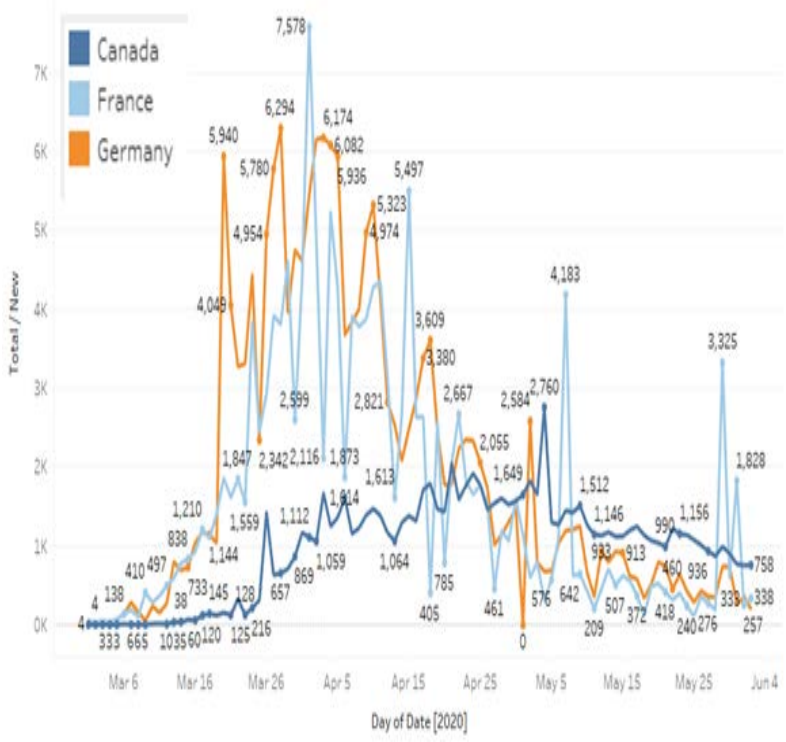

Figure. 4: COVID Daily Cases Curve of Canada, France, Germany

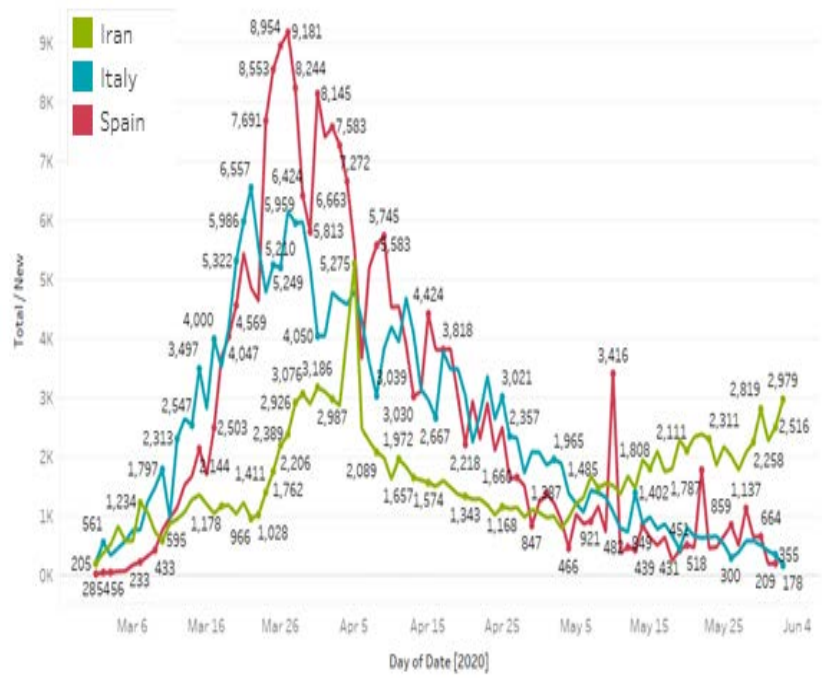

Figure. 5: COVID Daily Cases Curve of Iran, Italy, Spain

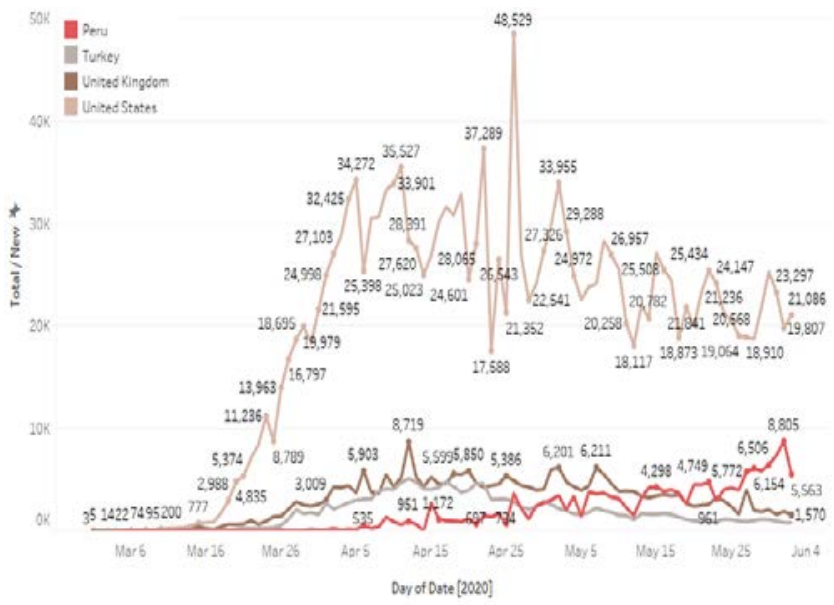

Figure. 6: COVID Daily Cases Curve of Peru, Turkey, UK, US

Almost all countries in these 10 had been gone through lockdown at the initial state except the United States. The maximum/peak points of daily confirmed cases are noted. All of these countries, curves start bending after this peak value. Now, if we compare this peak point total cases with the total population then almost the same ratio (Table No.: 5) has been achieved for all of these countries. It has been noted that besides lockdown this ratio $\left(\mathrm{C}_{\mathrm{PR}}\right)$ is approximately the same for all of these countries ${ }^{25)}$.

So, it has seemed that the population act a major role in predicting the COVID-19 cases for any country. It is also observed despite of lockdown, any country will be having approximately cases equal to:

$\mathrm{C}_{\mathrm{PR}} *$ Population of Country.

The total cases on $2^{\text {nd }}$ June are also observed in the table, at this point these countries' graph came close to zero or bare minimum after the peak point achieved. A ratio $\mathrm{T}_{\mathrm{PR}}$ is calculated here, i.e. the ratio of total cases to the population of the country. This ratio established a connection for total cases where the graph flattens and daily cases at its lowest values 


\begin{tabular}{|c|c|c|c|c|c|c|c|}
\hline \multirow[b]{2}{*}{$\begin{array}{l}\text { Sr. } \\
\text { No. }\end{array}$} & \multirow[b]{2}{*}{ Country } & \multirow[b]{2}{*}{ Population } & \multicolumn{5}{|c|}{ Confirmed Cases } \\
\hline & & & $\begin{array}{l}\text { Peak } \\
\text { Day: } \\
\text { Highest } \\
\text { Cases }\end{array}$ & $\begin{array}{l}\text { Total } \\
\text { Confirmed } \\
\text { Cases at till } \\
\text { Peak }\end{array}$ & $\begin{array}{l}\text { At Peak: } \\
\% \quad \text { Cases of } \\
\text { Total } \\
\text { Population }\end{array}$ & $\begin{array}{l}\text { Total Cases } \\
\text { on 2nd } \\
\text { June }\end{array}$ & $\begin{array}{l}\text { 2nd June: } \\
\text { \% Cases of } \\
\text { Total } \\
\text { Population }\end{array}$ \\
\hline 1 & $\begin{array}{l}\text { United } \\
\text { States }\end{array}$ & $331,002,647$ & 48,529 & 939,053 & $0.2837 \%$ & $1,811,277$ & $0.5472 \%$ \\
\hline 2 & Russia & $145,934,460$ & 11,656 & 221,344 & $0.1517 \%$ & 414,741 & $0.2842 \%$ \\
\hline 3 & $\begin{array}{l}\text { United } \\
\text { Kingdom }\end{array}$ & $67,886,004$ & 8,719 & 78,991 & $0.1164 \%$ & 276,332 & $0.4071 \%$ \\
\hline 4 & Spain & $46,754,783$ & 9,181 & 75,641 & $0.1618 \%$ & 239,638 & $0.5125 \%$ \\
\hline 5 & Italy & $60,461,828$ & 6,557 & 53,578 & $0.0886 \%$ & 233,197 & $0.3857 \%$ \\
\hline 6 & Germany & $83,783,945$ & 6,294 & 48,582 & $0.0580 \%$ & 182,028 & $0.2173 \%$ \\
\hline 7 & Turkey & $84,339,067$ & 5,138 & 52,167 & $0.0619 \%$ & 164,769 & $0.1954 \%$ \\
\hline 8 & Iran & $83,992,953$ & 5,275 & 55,743 & $0.0664 \%$ & 154,445 & $0.1839 \%$ \\
\hline 9 & France & $65,273,512$ & 7,578 & 52,128 & $0.0799 \%$ & 152,091 & $0.2330 \%$ \\
\hline 10 & Canada & $37,742,157$ & 2,760 & 59,474 & $0.1576 \%$ & 91,694 & $0.2429 \%$ \\
\hline & $\mathrm{C}_{\mathbf{P R}}=$ & & & & $0.1047 \%$ & $\mathbf{T}_{\mathrm{PR}}=$ & $0.2958 \%$ \\
\hline
\end{tabular}

Table No.: 5*: Peak points of daily confirmed cases

While calculating $\mathrm{C}_{\mathrm{PR}} \& \mathrm{~T}_{\mathrm{PR}}$ United States was excluded because US did not apply the lockdown at the corona's initial stage, other countries applied it at some initial stage.

Let us have a look at India's current number of COVID-19:

\begin{tabular}{|l|l|l|l|l|l|}
\hline \multirow{4}{*}{ India Data till Now } \\
\hline & & Total & Total & & \\
ry & Pount & Cases & Deat & Total & Total \\
on & hs on & Recover & Tests as \\
& & $\begin{array}{l}\text { 2nd } \\
\text { 2nd }\end{array}$ & ed & on date \\
\hline India & $1,350,000$, & 198,7 & 5,598 & 104,242 & $3,737,0$ \\
& 000 & 06 & & & 27 \\
\hline
\end{tabular}

Using these $\mathbf{C}_{\mathbf{P R}}$ and $\mathbf{T}_{\mathbf{P R}}$ values the peak value and total cases at the flattening curve can be estimated for India.

Considering the population of India let us calculate predicted values for India:

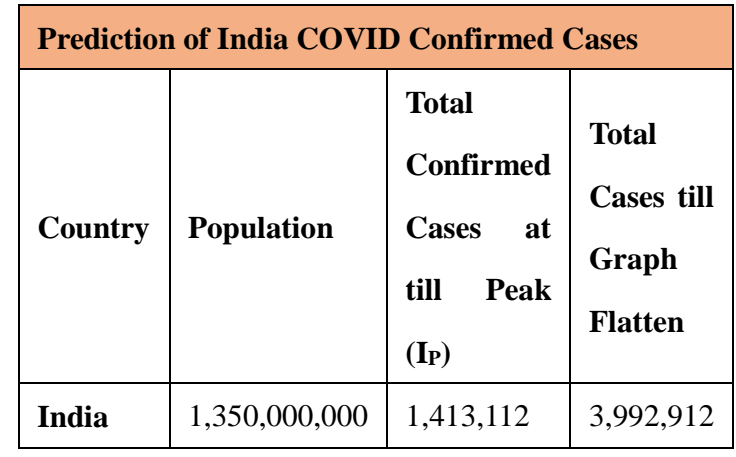

India current graph as per the data till $2^{\text {nd }}$ June 2020:

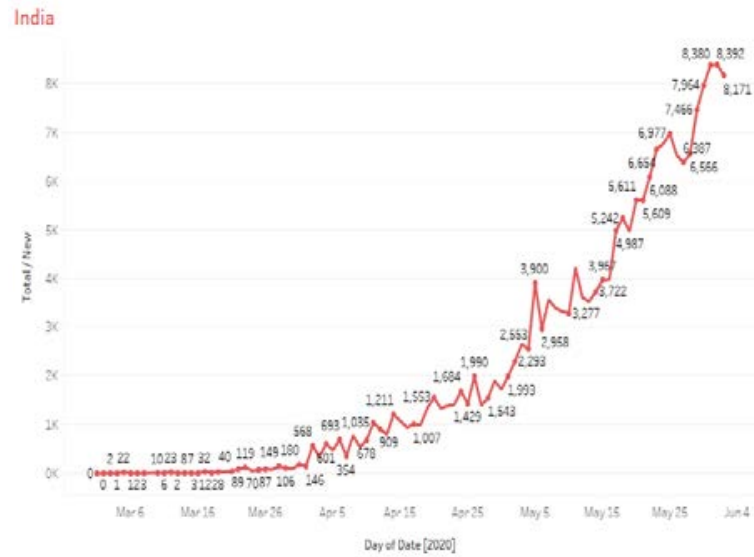

Figure. 7: India current Daily COVID Cases Curve 
Now consider the average current rate of daily cases as $\mathbf{C}_{\mathbf{R}}$ \& applying the regression model to predict the future values of daily cases. When the cases reach the $\mathrm{I}_{\mathrm{P}}$ (peak values) then the $\mathbf{C}_{\mathbf{R}}$ for the model will start decreasing.

Daily Cases $\left(\mathrm{D}_{\mathrm{C}}\right)=$ Total Cases*

(CR \%).

(Till $\mathrm{D}_{\mathrm{C}}<$ $\left.\mathrm{I}_{\mathrm{P}}\right)$

Daily Cases $\left(\mathrm{D}_{\mathrm{C}}\right)=$ Total Cases $*\left(\mathbf{C}_{\mathbf{R}(\mathbf{t}-\mathbf{1})}-\left(\mathbf{C}_{\mathbf{R}(\mathbf{t}-\mathbf{1})}\right.\right.$ *5\%)). .. (Till $\mathrm{D}_{\mathrm{C}}>\mathrm{I}_{\mathrm{P}}$ )

Where t refers to the current day, $\mathbf{C}_{\mathbf{R}(\mathbf{t}-1)}$ is value of $\mathbf{C}_{\mathbf{R}}$ at t-1 day (i.e. previous day).

After applying the parameters to the model, the model gave the daily case values and total cases. These values are plotted (Figure:8, which gives a very accurate prediction of the COVID-19 cases). The R-Squared value of predicted confirmed cases is $96.67 \%$.

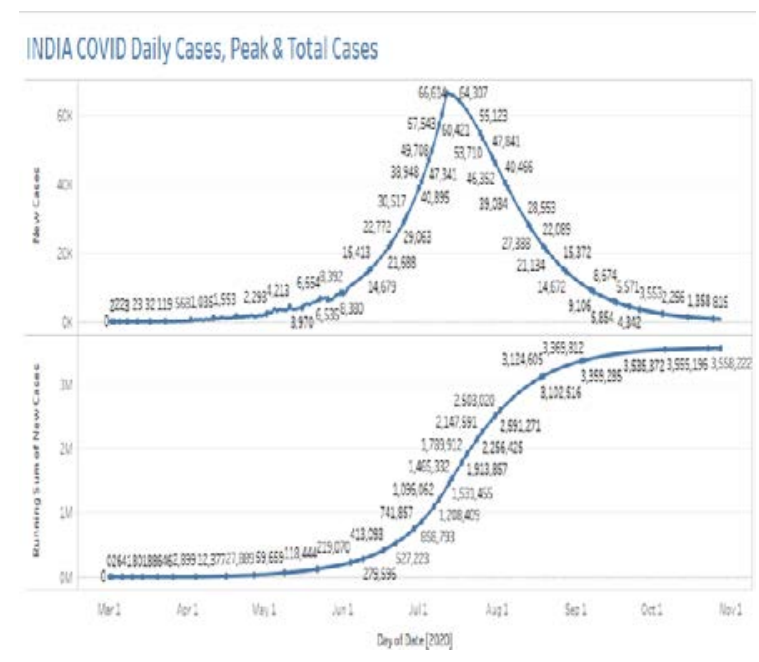

Figure. 8: India predicted Daily New and Total COVID Cases Curve (With Peak)

It is seen from the prediction model that a peak of India COVID total cases will be in $1^{\text {st }}$ week of July, at this point, the daily cases are its peak i.e. $\mathrm{C}_{\mathrm{PR}} \%$ of the total population of India and after this week the curves start bending. The total cases curve will also start flatten in the month of August/September. So, using this, the country can plan for health care needs.

\section{A predictive model of COVID Deaths}

The same phenomena are used while calculating the total deaths due to COVID-19 for any country. Only the difference is now the ration $\mathrm{D}_{\mathrm{PR}}$ (Deaths at Peak) \& $\mathrm{TD}_{\mathrm{PR}}$ (Total deaths till curve flatten) are calculated over the total number of cases at peak inspite of population. (Refer table No.6)

Using these $\mathbf{D}_{\mathbf{P R}}$ and $\mathbf{T D}_{\mathbf{P R}}$ deaths at peak and total deaths until the curve flatten are calculated as follows:

\begin{tabular}{|l|l|ll|}
\hline \multicolumn{3}{|l|}{ Prediction of India COVID Deaths } \\
\hline & Total Deaths & Total & Deaths \\
Country & till Peak & till & Graph \\
& $\left(D_{P}\right)$ & Flatten & \\
\hline India & 81,384 & 346,036 & \\
\hline
\end{tabular}

Table No: 6: Total deaths till curve flatten

\begin{tabular}{|c|c|c|c|c|c|c|}
\hline \multirow[b]{2}{*}{$\begin{array}{l}\text { Sr. } \\
\text { No }\end{array}$} & \multirow[b]{2}{*}{$\begin{array}{l}\text { Countr } \\
\mathbf{y}\end{array}$} & \multicolumn{5}{|c|}{ Mortality } \\
\hline & & $\begin{array}{l}\text { Peak } \\
\text { Day: } \\
\text { Highe } \\
\text { st } \\
\text { Death } \\
\text { s }\end{array}$ & $\begin{array}{l}\text { Total } \\
\text { Death } \\
\text { s till } \\
\text { Peak }\end{array}$ & $\begin{array}{l}\text { At } \\
\text { Peak: } \\
\% \\
\text { Death } \\
\text { s of } \\
\text { Total } \\
\text { Cases } \\
\text { (DPR) }\end{array}$ & $\begin{array}{l}\text { Total } \\
\text { Death } \\
\text { s on } \\
\text { 2nd } \\
\text { June }\end{array}$ & $\begin{array}{l}\text { 2nd } \\
\text { June: } \\
\% \\
\text { Death } \\
\quad \text { of } \\
\text { Total } \\
\text { Cases } \\
\text { (DTR) }\end{array}$ \\
\hline 1 & $\begin{array}{l}\text { United } \\
\text { States }\end{array}$ & 2,172 & $\begin{array}{l}53,18 \\
9\end{array}$ & $5.66 \%$ & $\begin{array}{l}105,14 \\
7\end{array}$ & $5.81 \%$ \\
\hline 2 & Russia & 94 & 2,009 & $0.91 \%$ & 5,037 & $1.21 \%$ \\
\hline 3 & $\begin{array}{l}\text { United } \\
\text { Kingdo } \\
\text { m }\end{array}$ & 839 & $\begin{array}{l}11,59 \\
9\end{array}$ & $\begin{array}{l}14.68 \\
\%\end{array}$ & 39,045 & $\begin{array}{l}14.13 \\
\%\end{array}$ \\
\hline 4 & Spain & 655 & 4,089 & $5.41 \%$ & 27,940 & $\begin{array}{l}11.66 \\
\%\end{array}$ \\
\hline 5 & Italy & 795 & 4,827 & $9.01 \%$ & 33,475 & $\begin{array}{l}14.35 \\
\%\end{array}$ \\
\hline 6 & $\begin{array}{l}\text { Germa } \\
\text { ny }\end{array}$ & 72 & 325 & $0.67 \%$ & 8,522 & $4.68 \%$ \\
\hline 7 & Turkey & 95 & 1,101 & $2.11 \%$ & 4,563 & $2.77 \%$ \\
\hline 8 & Iran & 292 & 3,452 & $6.19 \%$ & 7,878 & $5.10 \%$ \\
\hline 9 & France & 499 & 3,523 & $6.76 \%$ & 28,833 & $\begin{array}{l}18.96 \\
\%\end{array}$ \\
\hline 10 & Canada & 116 & 3,682 & $6.19 \%$ & 7,326 & $7.99 \%$ \\
\hline & & & $\mathbf{D}_{\mathrm{PR}}=$ & $\begin{array}{l}5.76 \\
\%\end{array}$ & $\begin{array}{l}\text { TDPR } \\
=\end{array}$ & $\begin{array}{l}8.67 \\
\%\end{array}$ \\
\hline
\end{tabular}

Now consider the average current rate of daily deaths as $\mathbf{D}_{\mathbf{R}}$ \& applying the regression model to predict the future values of daily deaths.

Daily Deaths $\left(\mathrm{D}_{\mathrm{D}}\right)=$ Total Cases $*\left(\mathbf{D}_{\mathbf{R}} \%\right)$

After applying the death parameters to the model, it gave the daily deaths and total deaths. These values are 
plotted (Figure:9, which gives a very accurate prediction of the COVID-19 deaths). The R-Squared value of predicted deaths is $92.13 \%$.

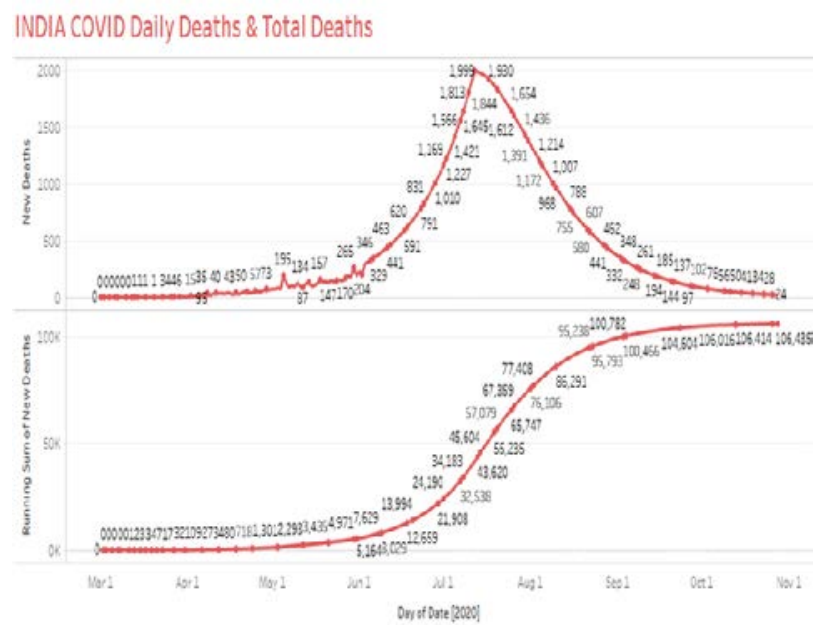

Figure $^{18)}$. 9: India predicted Daily and Total COVID Deaths Curve (With Peak)

The predictive model of COVID Recovered Cases

A model is also formed to predict the recovery rate, total recovery until the graph flattens and total test to be conducted versus population until any country's graph started to flatten. A data is collected for the same top 10 countries and an average of percent total recovery over total confirmed cases is calculated for modelling. (Refer Table: 7)

Table: 7: Average of percent total recovery over total confirmed cases

\begin{tabular}{|c|c|c|c|c|c|c|}
\hline \multirow[b]{2}{*}{$\begin{array}{l}\mathrm{S} \\
\mathbf{r} \\
\text {. } \\
\mathrm{N} \\
\mathrm{o}\end{array}$} & \multirow[b]{2}{*}{$\begin{array}{l}\text { Cou } \\
\text { ntry }\end{array}$} & \multicolumn{2}{|c|}{ Recovered Cases } & \multicolumn{3}{|c|}{ Test Conducted } \\
\hline & & $\begin{array}{l}\text { Total } \\
\text { Reco } \\
\text { vered } \\
\text { Till } \\
\text { Date }\end{array}$ & $\begin{array}{l}\text { \% Total } \\
\text { Recover } \\
\text { ed of } \\
\text { Total } \\
\text { Confirm } \\
\text { ed }\end{array}$ & $\begin{array}{l}\text { Total } \\
\text { Tests } \\
\text { as on } \\
\text { date }\end{array}$ & $\begin{array}{l}\text { \% } \\
\text { Total } \\
\text { Tests of } \\
\text { Populat } \\
\text { ion }\end{array}$ & $\begin{array}{l}\% \\
\text { Confirm } \\
\text { ed Cases } \\
\text { of Total } \\
\text { Test } \\
\text { Conduct } \\
\text { ed }\end{array}$ \\
\hline 1 & $\begin{array}{l}\text { Unit } \\
\text { ed } \\
\text { Stat } \\
\text { es }\end{array}$ & $\begin{array}{l}688,6 \\
92\end{array}$ & $38.02 \%$ & $\begin{array}{l}16,93 \\
6,891\end{array}$ & $5.12 \%$ & $10.69 \%$ \\
\hline 2 & $\begin{array}{l}\text { Rus } \\
\text { sia }\end{array}$ & $\begin{array}{l}204,6 \\
23\end{array}$ & $49.34 \%$ & $\begin{array}{l}10,92 \\
3,108\end{array}$ & $7.48 \%$ & $3.80 \%$ \\
\hline 3 & $\begin{array}{l}\text { Unit } \\
\text { ed }\end{array}$ & $\begin{array}{l}\text { Not } \\
\text { Avail } \\
\text { able }\end{array}$ & -- & $\begin{array}{l}2,144, \\
626\end{array}$ & $3.16 \%$ & $12.88 \%$ \\
\hline
\end{tabular}

\begin{tabular}{|c|c|c|c|c|c|c|}
\hline & $\begin{array}{l}\text { Kin } \\
\text { gdo } \\
\text { m }\end{array}$ & & & & & \\
\hline 4 & $\begin{array}{l}\text { Spai } \\
\text { n }\end{array}$ & $\begin{array}{l}150,0 \\
00\end{array}$ & $62.59 \%$ & $\begin{array}{l}2,536, \\
234\end{array}$ & $5.42 \%$ & $9.45 \%$ \\
\hline 5 & $\begin{array}{l}\text { Ital } \\
\mathbf{y}\end{array}$ & $\begin{array}{l}160,9 \\
38\end{array}$ & $69.01 \%$ & $\begin{array}{l}3,910, \\
133\end{array}$ & $6.47 \%$ & $5.96 \%$ \\
\hline 6 & $\begin{array}{l}\text { Ger } \\
\text { man } \\
\text { y }\end{array}$ & $\begin{array}{l}167,8 \\
00\end{array}$ & $92.18 \%$ & $\begin{array}{l}3,952, \\
971\end{array}$ & $4.72 \%$ & $4.60 \%$ \\
\hline 7 & $\begin{array}{l}\text { Tur } \\
\text { key }\end{array}$ & $\begin{array}{l}130,8 \\
52\end{array}$ & $79.42 \%$ & $\begin{array}{l}2,070, \\
719\end{array}$ & $2.46 \%$ & $7.96 \%$ \\
\hline 8 & Iran & $\begin{array}{l}127,4 \\
85\end{array}$ & $82.54 \%$ & $\begin{array}{l}935,8 \\
94\end{array}$ & $1.11 \%$ & $16.50 \%$ \\
\hline 9 & $\begin{array}{l}\text { Fra } \\
\text { nce }\end{array}$ & $\begin{array}{l}69,45 \\
5\end{array}$ & $45.67 \%$ & $\begin{array}{l}1,384, \\
633\end{array}$ & $2.12 \%$ & $10.98 \%$ \\
\hline 1 & $\begin{array}{l}\text { Can } \\
\text { ada }\end{array}$ & $\begin{array}{l}51,04 \\
8\end{array}$ & $55.67 \%$ & $\begin{array}{l}\text { 1,691, } \\
297\end{array}$ & $4.48 \%$ & $5.42 \%$ \\
\hline & & RPR & $63.83 \%$ & TSPR $_{P}$ & $4.16 \%$ & $8.62 \%$ \\
\hline
\end{tabular}

Where $\mathbf{R}_{\mathbf{P R}}$ is the recovery rate of total confirmed cases and TSpr is the percent total test to be conducted over population until the graph flattens of any country. Using $\mathbf{R}_{\mathbf{P R}}$ and TSPR values of total recovered cases and total test to be conducted till graph flatten are calculated as follows:

\begin{tabular}{|c|c|c|c|c|c|}
\hline \multirow[b]{2}{*}{$\begin{array}{l}\text { Coun } \\
\text { try }\end{array}$} & \multicolumn{2}{|c|}{$\begin{array}{l}\text { Prediction } \\
\text { Based on Tests } \\
\text { Conduction }\end{array}$} & \multicolumn{3}{|c|}{$\begin{array}{c}\text { Prediction } \\
\text { Recovered Cases }\end{array}$} \\
\hline & $\begin{array}{l}\text { Test } \\
\text { Cond } \\
\text { ucted } \\
\text { Till } \\
\text { date }\end{array}$ & $\begin{array}{l}\text { Total } \\
\text { Tests of } \\
\text { Popula } \\
\text { tion } \\
\text { will be } \\
\text { conduc } \\
\text { ted till } \\
\text { graph } \\
\text { Flatten }\end{array}$ & $\begin{array}{l}\text { Curr } \\
\text { ent } \\
\text { Reco } \\
\text { very } \\
\text { Rate }\end{array}$ & $\begin{array}{l}\text { Total } \\
\text { Reco } \\
\text { vered } \\
\text { at } \\
\text { Grap } \\
\text { h } \\
\text { Flatt } \\
\text { en }\end{array}$ & $\begin{array}{l}\text { India } \\
\text { \% age } \\
\text { of } \\
\text { recover } \\
\text { ed } \\
\text { cases at } \\
\text { Graph } \\
\text { Flatten }\end{array}$ \\
\hline India & $\begin{array}{l}3,737, \\
027\end{array}$ & $\begin{array}{l}56,160, \\
000\end{array}$ & $\begin{array}{l}R_{R}= \\
45 \%\end{array}$ & $\begin{array}{l}2,677 \\
, 248\end{array}$ & $66.89 \%$ \\
\hline
\end{tabular}


It has been seen that till India graph flatten total approximate 5.62 Crore test to be conducted and the recovery rate per day will be $67 \%$ till graph flatten. After applying the regression model, the graph was plotted for the daily recovered cases in India (figure 10).

Daily Recovered Cases $\left(\mathrm{R}_{\mathrm{D}}\right)=$ Total Cases $*\left(\mathrm{R}_{\mathrm{R}(\mathrm{t}-\mathbf{1})}+\right.$ $\left.\left(\mathrm{R}_{\mathrm{R}(\mathrm{t}-1)} * 0.25 \%\right)\right)$

Where $t$ refers to the current day, $\mathbf{R}_{\mathbf{R}(t-1)}$ is value of $R_{\mathbf{R}}$ at $\mathrm{t}-1$ day (i.e. previous day). The R-Squared value of predicted recovered cases is $98.1 \%$.

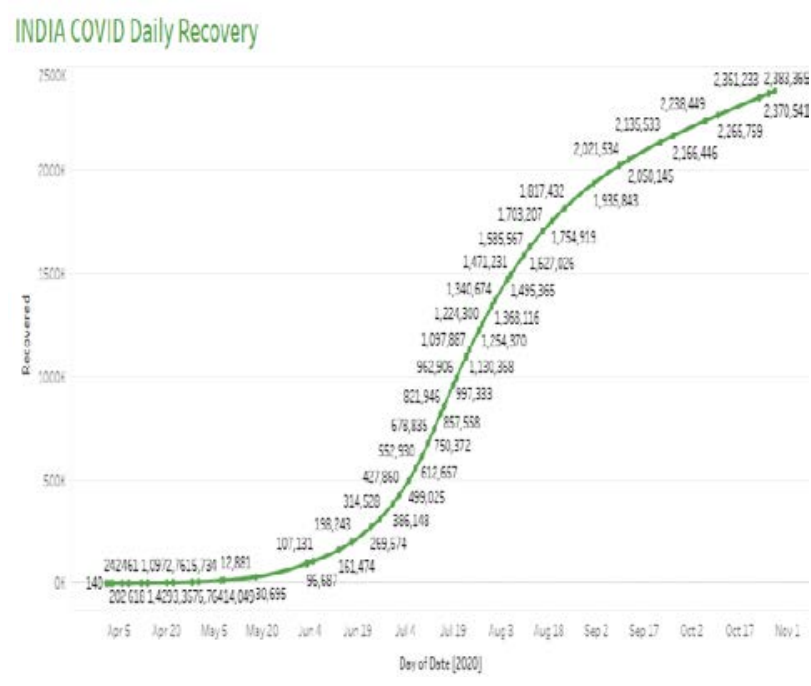

Figure. 10: India recovered Total COVID Cases Curve

The model has been built for prediction of COVID confirmed cases, peak confirmed cases, deaths, peak deaths and recovery rate. The model is self-explanatory and well established. The actual data of top 15 countries till $2^{\text {nd }}$ June 2020 was used to build the model.

\section{Conclusion}

The actual data of the top 15 countries till $2^{\text {nd }}$ June 2020 was used to build the model. We have analyzed the data of Covid-19 spread in India in current scenarios. A mathematical model is established following the actual data trend of Covid-19 spread in India. This model can find an approximate fatality rate in India. The performance of the model is evaluated and compared with available data. The calculated value of correlation coefficient indicating that the mortality rate will linearly increase with the increase of corona infected cases and t-test confirms our null hypothesis that the maximum average death rate in India could be $3.49 \%$. As future work we are planning to collect the data in order to collect more information related to $3.49 \%$ death cases due to COVID-19. It has been observed that countries with lockdown are still having a total COVID case equal to CPR percent of its population and total cases till the country graph flatten will be $\mathbf{T}_{\mathbf{P R}}$ percent of the total population because of virus. After this much spread only any country can be in the state of bending the curve for daily cases and flatten curve for total cases. It is also found that total deaths till any country flatten the curve will approximately DPR percent of its total population. The recovery rate is quite good for lockdown countries i.e. $67 \%$ till they reach the peak and which is further improving as soon as daily cases reach to minimum/zero. Regarding Coronavirus testing, it's found that a country will be doing an approximate $4 \%$ test of its population till reaching the end of the pandemic/graph flattens. Sharing information can help researchers and governments to understand the mortality rate during virus transmission. The results also found that regression could give initial an indicator of the possibility of surviving or dying, based on the collected data.

Funding: No funding sources and no competing interest.

Ethical Approval: No ethical approval is required.

Conflicts of Interest Statement: The authors have no affiliations with or involvement in any organization or entity with any financial interest (such as honoraria; educational grants; participation in speakers' bureaus; membership, employment, consultancies, stock ownership, or other equity interest; and expert testimony or patent-licensing arrangements), or non-financial interest (such as personal or professional relationships, affiliations, knowledge or beliefs) in the subject matter or materials discussed in this manuscript.

\section{References}

1) I. Turaiki, M. Alshahrani, T. Almutairi, "Building predictive models for Mers-CoV infections using data mining techniques”. Journal of Infection and Public Health 2016: 9,744-748.

2) N. Zhu, D. Zhang, W. Wang, X. Li, B. Yang, J. Song, "China novel coronavirus investigating and research team”. A novel coronavirus from patients with pneumonia in China, 2019. N Engl J Med 2020; 382: 727-33.

3) D. Wang, B. Hu, C. Hu, F. Zhu, X. Liu X, J. Zhang, "Clinical characteristics of 138 hospitalized patients with 2019 novel coronavirus-infected pneumonia in Wuhan”, China. JAMA 2020; 323: 1061-9.

4) Z. Wu, J.M. McGoogan, "Characteristics of and important lessons from the coronavirus disease 2019 (COVID-19) outbreak in China: Summary of a report of 72314 cases from the Chinese center for Disease Control and Prevention”. JAMA 2020; 323: 1239-42.

5) W.J. Guan, Z.Y. Ni, Y. Hu, W.H. Liang, "Clinical characteristics of coronavirus disease 2019 in China”. N Engl J Med 2020; 382: 1708-20.

6) G. Grassell, A. Zangrillo, M. Antonelli, L. Cabrini, A. Castelli, "Baseline characteristics and outcomes of 1591 patients infected with SARS-CoV-2 admitted to ICUs of the Lombardy region, Italy”. JAMA 2020; 323: 1574-81.

7) S. Richardson, J.S. Hirsch, M. Narasimhan, J.M. Crawford, T. McGinn, K.W. Davidson, "Presenting 
characteristics, co-morbidities and outcomes among 5700 patients hospitalized with COVID-19 in the New York city area”. JAMA 2020; 323: 2052-9.

8) World Health Organization. Coronavirus Disease 2019 (COVID-19) Situation Report 68, 28 ${ }^{\text {th }}$ March 2020 (2020); https://www.who.int/docs/default-source/coronaviru s /situation-reports/20200328-sitrep-68-covid-19.pdf

9) C. Huang, "Clinical features of patients infected with 2019 novel coronavirus in Wuhan”, China. Lancet 2020: 395, 497-506.

10) L. Zhonghua, B. Xing, Z. Xue. "Novel Coronavirus Pneumonia Emergency Response Epidemiology Team The epidemiological characteristics of an outbreak of 2019 novel coronavirus diseases (COVID-19) in China”. 2020: 41, 145-151.

11) M.A. Andrews, B. Areekal, K.R. Rajesh, J. Krishnan, R. Suryakala, B. Krishnan, "First confirmed case of COVID-19 infection in India”: A case report. Indian J Med Res 2020; 151: 490-2.

12) "India most infected by Covid-19 among Asian countries, leaves Turkey behind". Hindustan Times. $29^{\text {th }}$ May 2020. Retrieved 30 ${ }^{\text {th }}$ May 2020.

13) "Home | Ministry of Health and Family Welfare | GOI". mohfw.gov.in. Retrieved 30 May 2020.

14) World Health Organization (WHO) Coronavirus Disease (COVID-19) Dashboard Data last updated: 2020/5/29, 7:02pm CEST https://covid19.who.int.

15) "Coronavirus pandemic (COVID-19) in India". Our World in Data. Retrieved 20 $0^{\text {th }}$ May 2020.

16) J.H. Yoo, S.T. Hong, "The outbreak cases with the novel coronavirus suggest upgraded quarantine and isolation in Korea”. Journal of Korean Medical Science, 35(5) (2020).

17) Korea Centers for Disease Control and Prevention (2020).

http://ghdx.healthdata.org/organizations/korea-center s-disease-control-and-prevention-kcdc

18) New COVID-19 cases in India by state and union territory.https://en.wikipedia.org/wiki/COVID-19_pa ndemic in_India\#Escaping of suspected_people

19) P. Tungjiratthitikan, "Accidents in Thai Industry between 2001 and 2017”, Evergreen Joint Journal of Novel Carbon Resource Sciences \& Green Asia Strategy, Vol. 05, Issue 02, pp.86-92, June 2018.

20) S. Kitjanukit, "Attitude toward Bio remediation Related Technology and Relation with Company Social Responsibility”, Evergreen Joint Journal of Novel Carbon Resource Sciences \& Green Asia Strategy, Vol. 06, Issue 03, pp240-245, September, 2019.

21) M. Rahman, A. Pal, K. Uddin, T. Kyaw, B.B. Saha, "Statistical Analysis of Optimized Isotherm Model for Maxsorb III/Ethanol and Silica Gel/Water Pairs”, Evergreen Joint Journal of Novel Carbon Resource Sciences \& Green Asia Strategy, Vol. 05, Issue 04, pp.1-12, December 2018.

22) M.R. Bhatnagar, "COVID-19: Mathematical Modeling and Predictions", submitted to ARXIV. Online available at: http://web.iitd.ac.in/ manav/COVID.pdf [Accessed on April 01, 2020].

23) https://www.worldometers.info/coronavirus /\#countries [Accessed on June 02, 2020].

24) G.D. Nugraha, B. Sudiarto, R. Kalamullah, "Machine Learning-based Energy Management System for Prosumer”, Evergreen Joint Journal of Novel Carbon Resource Sciences \& Green Asia Strategy, Vol. 07, Issue 02, pp309-313, June, 2020.

25) N. Khan, M. Naushad, "Effects of Corona Virus on the World Community". Available at SSRN 3532001(2020). 